$\checkmark$ Research Square

\title{
Inhibition of Caspase-1 by VX-765 Reduces \\ Pyroptosis and Attenuates Neuroinflammation After Spinal Cord Injury
}

Keywords:

Posted Date: March 8th, 2021

DOI: https://doi.org/10.21203/rs.3.rs-92181/v2

License: (c) (i) This work is licensed under a Creative Commons Attribution 4.0 International License.

Read Full License 


\section{Abstract}

The authors have requested that this preprint be removed from Research Square. 